\title{
A SZINGAPÚRI SIKERTÖRTÉNET MAGYAR SZEMMEL
}

Szingapúr időről időre felkelti a hazai közönség érdeklődését - legutóbb, amikor a Világgazdasági Fórum 2019-es globális versenyképességi jelentéséből kiderült, hogy Szingapúr, az USA-t megelőzve, a versenyképességi rangsor élére került. 2003-ban magyar nyelven is megjelent a több mint harminc évet (1959-1990) a szingapúri miniszterelnöki pozíciót betöltő Lee Kuan Yew (Li Kuang-jao) könyve (A harmadik világból az elsőbe: A ,szingapúri sztori” 1965-2000: Szingapúr és Ázsia gazdasági fellendülése), aki a saját szemszögéből értelmezi a szingapúri csodát, és most került a polcokra Magasházi Anikó monográfiája, amely „magyar kitekintéssel” tárgyalja Szingapúr útját „a bérelőnytől az innovációvezérelt gazdaság felé".

Miért érdemes magyar kutatóknak Szingapúr gazdaságával foglalkozni? - merülhet fel a kérdés az olvasóban. A Világbank egy 2013-as kiadványában (China 2030: Building a Modern, Harmonious, and Creative Society) jelent meg az az elgondolkodtató adat, miszerint az 1960-ban közepes jövedelmủ országként nyilvántartott százegy ország közül mindössze tizenháromnak sikerült egy fél évszázad elteltével a magas jövedelmủ országok klubjába bekerülnie. Ráadásul, ez utóbbiak közül sem mindannyian a nagykönyvben leírt módon, vagyis széles körű szakértői bázison alapuló stratégiai tervezés és szisztematikusan végrehajtott modernizációs stratégia eredményeként kerültek a klubba, hanem például a területükön felfedezett kőolajnak köszönhetően.

Mivel azonban Szingapúr tankönyvi példája lehet egy sikeres modernizációs stratégiát végrehajtó fejlesztő államnak, amely a közepes jövedelmi csapdát leküzdve a technológiai és versenyképességi élvonalba került, egy olyan könyv, amely megismertet e tudatos és egyúttal pragmatikus fejlesztési stratégia részleteivel, széles körü érdeklődésre tarthat számot.

Ráadásul, a tanulságokat magyar szemszögböl vizsgálva, sok az áthallás. A hosszú távú gondolkodás hangsúlyozása mellett a szerző számos példával érzékelteti a pragmatikus hozzáállás jelentőségét is, azt, hogy a stratégiai terv végrehajtása során a szakpolitika teret engedett a visszacsatolásoknak, és a tanulságokat levonva, a szakértőkkel konzultálva, gyakran került sor a prioritásoknak, sőt akár a gazdaságfejlesztés vezérlő elveinek módosítására is.

Magyar szemszögből igen tanulságos, hogy milyen fontos szerepet játszott Szingapúr kiemelkedésében az oktatási rendszer és a munkaerő minöségének fejlesztése, és fóként, hogy a szingapúri oktatási rendszer legalább akkora súlyt helyez a felzárkóztatásra, mint a kiválóság ösztönzésére. A felzárkóztatás sikerét a PISA-eredmények (a 2015-ös adatok szerint, Szingapúr mindhárom mért 
készség tekintetében az első, a 2018-as adatok szerint pedig a második helyezett a világon), a kiválóság ösztönzésének eredményességét pedig a globális egyetemi rangsorok tükrözik. A 2020-as QS World University Ranking adatai szerint az első húsz egyetem között két szingapúri található, olyan intézményeket utasítva maguk mögé, mint a Princeton, a Yale vagy a Columbia. Lehetetlen áthallás nélkül olvasni, hogy a sikerhez az is hozzájárult, hogy fokozatosan erősödött az oktatási intézmények önállósága.

A minöségi fejlesztést tükrözi egy, a recenzió írásakor megjelent friss adat is, jelesül, hogy a robotsürüség (a tízezer ipari foglalkoztatottra jutó ipari robotok száma) ma Szingapúrban a legmagasabb a világon. (A világátlag 99, Szingapúrban a mutató értéke 831, és még Németországban is csupán 338 - International Federation of Robotics.)

Egy másik áthallásos részlet a közvetlentőke-vonzási stratégiát tárgyalja. A könyv bemutatja, miként érte el Szingapúr, hogy ne váljon egyetlen ágazat (az elektronikai ipar) dominánssá a közvetlentőke-befektetések vezérelte modernizáció időszakában, és miként diverzifikálták az ágazati szerkezetet a tőkebefektetések „stratégiai terelésével”. A globalizációból fakadó lehetőségek és előnyök kihasználása napjainkban is folytatódik: ahogy Szingapúr tudatosan integrálódik a globális innovációs hálózatokba, a külföldi tőke egyre magasabb helyi hozzáadott értéket produkáló tevékenységekbe áramlik.

A könyvből egyértelműen kiderül, hogy a globális értékláncokba történő integrálódás előnyeit akkor tudja kihasználni egy ország, ha folyamatosan erősíti pozícióit az értékláncokon belül. Szingapúr ezt az intézményi rendszerének fejlesztésével, és immár magas jövedelmủ országként, napjainkban elsősorban a tudomány- és technológiapolitikájával valósítja meg.

Tanulságos részleteket olvashatunk arról, hogy milyen sokféle országos és helyi technológiai program és akcióterv eredményeként erősödött a tudás lokalizációja, és nőtt a helyben beszerzett inputok aránya, továbbá arról, hogy miként fókuszál a szakpolitika az újabb és újabb műszaki-gazdasági paradigmát meghatározó tudományágakra és technológiai területekre.

A könyv gondolatmenetét folytatva, tegyük hozzá, hogy legújabban a technológiai startupok szisztematikus fejlesztése és felvásárlása folyik. Ami a felvásárlásokat illeti, igen aktívak az állami vagyonalapok (Government Investment Corporation, Temasek), a fejlesztések első eredményeiről pedig a gyorsan növekvő értékủ, kockázati tőkével jól ellátott technológiai startupok tömege tanúskodik. A tudomány- és technológiapolitika legújabb fókuszterülete a mesterséges intelligencia: a 2017-ben meghirdetett ötéves, 110 millió dolláros mesterséges intelligencia fejlesztési program eredményeként az erre szakosodott startupok száma gyorsan nö.

A könyvet elolvasva sejteni véljük a sikeres fejlesztéspolitika receptjének öszszetevőit, és az is kiderül belőle, hogy a sikerhez nagyszámú tényező komplex 
együttállására van szükség. A tanulságok és áthallások inspirációt adhatnak: kiválóan alkalmasak arra, hogy pontosan értsük, mitől maradhat egy ország tartósan a modernizációs pályán, és melyek azok a pontok, ahol Magyarország utat tévesztett.

(Magasházi Anikó: Szingapúr globálisan behálózva - magyar kitekintéssel. Palánkai Tibor elöszavával. Köszeg-Szombathely: Felsöfokú Tanulmányok Intézete-Savaria University Press Alapitvány, 2018, 267 o.)

Szalavetz Andrea

DSc, Közgazdaság- és Regionális Tudományi Kutatóközpont Világgazdasági Intézet 